Research Article

\title{
Molecular cloning and functional analysis of the fatty acid-binding protein $(S p-F A B P)$ gene in the mud crab (Scylla paramamosain)
}

\author{
Xianglan Zeng, Haihui Ye, Ya'nan Yang, Guizhong Wang and Huiyang Huang \\ College of Ocean and Earth Sciences, Xiamen University, Xiamen, China
}

\begin{abstract}
Intracellular fatty acid-binding proteins (FABPs) are multifunctional cytosolic lipid-binding proteins found in vertebrates and invertebrates. In this work, we used RACE to obtain a full-length cDNA of Sp-FABP from the mud crab Scylla paramamosain. The open reading frame of the full length CDNA (886 bp) encoded a 136 amino acid polypeptide that showed high homology with related genes from other species. Real-time quantitative PCR identified variable levels of $S p-F A B P$ transcripts in epidermis, eyestalk, gill, heart, hemocytes, hepatopancreas, muscle, ovary, stomach and thoracic ganglia. In ovaries, $S p-F A B P$ expression increased gradually from stage I to stage IV of development and decreased in stage V. Sp-FABP transcripts in the hepatopancreas and hemocytes were up-regulated after a bacterial challenge with Vibrio alginnolyficus. These results suggest that Sp-FABP may be involved in the growth, reproduction and immunity of the mud crab.
\end{abstract}

Keywords: fatty acid-binding protein, immunity, ovary development, real-time quantitative PCR, Scylla paramamosain.

Received: July 5, 2012; Accepted: October 15, 2012.

\section{Introduction}

Fatty acid-binding proteins (FABPs) are small (14-15 $\mathrm{kDa})$, ubiquitous, multigenic cytosolic proteins that bind non-covalently to hydrophobic ligands, mainly fatty acids (FAs) (Esteves and Ehrlich, 2006). Apart from functioning as energy sources, FAs can act as signaling molecules (Sumida et al., 1993; Graber et al., 1994; Nunez, 1997) and regulate $\mathrm{Na}^{+}, \mathrm{K}^{+}, \mathrm{Ca}^{2+}$ and $\mathrm{Cl}^{-}$ion channels (Ordway et al., 1991; Kang and Leaf, 1996; Xiao et al., 1997; Liu et al., 2001). FAs also have a role in gene transcription, especially genes that encode proteins involved in lipid metabolism (DeWille and Farmer 1993; Martin et al., 1997; Clarke 2000; Louet et al., 2001). FABPs are therefore indirectly involved in biological responses mediated by FAs.

Since the isolation of the first invertebrate FABP from the desert locust, Schistocerca gregaria, by Haunerl and Chisholm (1990), a growing number of FABPs have been identified in invertebrates. In vertebrates and invertebrates, FABPs have a wide range of crucial biological roles, including the regulation of cellular lipid homeostasis, cell growth and differentiation, cellular signaling, gene transcription and cytoprotection (Zimmerman and Veerkamp, 2002). Studies in knockout mice have confirmed the importance of FABPs in the uptake and transport of long-chain fatty acids and their interaction with other transport systems and enzymes (Coburn et al., 2000). Moreover, studies

Send correspondence to Haihui Ye. College of Ocean and Earth Sciences, Xiamen University, 361005 Xiamen, China. E-mail: haihuiye@xmu.edu.cn. with the Chinese mitten crab Eriocheir sinensis have shown that $E s-F A B P$ expression levels vary with the stage of ovarian development (Gong et al., 2010).

FABPs may have a role in the immune reactions of invertebrates and vertebrates. Sm14, the first platyhelminth FABP isolated from the parasite Schistosoma mansoni (Moser et al., 1991), is a highly immunogenic peptide that offers important protection against experimental infections in cattle and other animals (Tendler et al., 1996). Homologous proteins such as $\mathrm{Sj-FABPc}$ from Schistosoma japonicum (Becker et al., 1994), Fh15 from Fasciola hepatica (Rodríguez-Pérez et al., 1992) and FgFABP from Fasciola gigantic (Estunningsih et al., 1997) also provide protection from challenge with infectious agents. In crustaceans, FABPs are known to be correlated with immunity. In Litopenaeus vannamei (Zhao et al., 2007), Penaeus stylirostris (Dhar et al., 2003), Procambarus clarkii (Zeng and Lu, 2009) and Fenneropenaeus chinensis (Wang et al., 2008; Ren et al., 2009) the expression levels of FABPs were up-regulated after a challenge with infectious agents.

Mud crabs (Scylla spp.) are a group of four commercially important Portunid species that are found in intertidal and subtidal, sheltered, soft-sediment habitats, particularly mangroves, throughout the Indo-Pacific region (Le Vay et al., 2008). In this report, we provide the first description of the cDNA structure, phylogenetic relationships and tissue distribution of an intracellular FABP from the mud crab Scylla paramamosain. The levels of $S p-F A B P$ expression 
in different stages of ovarian development and after microbial infection were also examined.

\section{Material and Methods}

\section{Tissue preparation}

Healthy adult female crabs were purchased from a local market in Xiamen, Fujian Province, China. Samples from ten tissues (epidermis, eyestalk, gills, heart, hemocytes, hepatopancreas, muscle, ovary, stomach and thoracic ganglia) were collected. The ovarian samples were collected based on the classification of Shangguan and Liu (1991) for ovarian developmental stages I (undeveloped), II (early-developing), III (developing), IV (nearly ripe) and $\mathrm{V}$ (ripe). All tissues were immediately frozen in liquid nitrogen and stored at $-80^{\circ} \mathrm{C}$ until nucleic acid extraction.

For the immune challenge, $S$. paramamosain crabs from Dongshan farm in Zhangzhou, Fujian Province, China, were injected with Vibrio alginnolyficus $\left(1 \times 10^{7}\right.$ $\mathrm{CFU} / \mathrm{mL} ; 20 \mu \mathrm{L})$ at the base of the right fourth pleopod (Cheng et al., 2004). Control crabs were injected with an equal volume of sterile saline solution. A total of 24 crabs per group were used, with three crabs for each time interval. At 0 (basal), 3, 6, 12, 24, 48, 72 and $96 \mathrm{~h}$ post-injection the hepatopancreas and hemocytes were collected from individuals injected with saline (control) or $V$. alginnolyficus and preserved with RNAsafer stabilizer reagent (TaKaRa, Japan).

\section{Nucleic acid extraction}

RNA was extracted using Trizol reagent (Invitrogen, USA) according to the manufacturer's protocol. The RNA concentration and quality were assessed spectrophotometrically based on the absorbance of $260 \mathrm{~nm}$ (NanoDrop Technologies, Inc., USA) and by agarose gel electrophore- sis, respectively. Total RNA was reverse transcribed using a PrimeScript RT-PCR kit with oligo $(\mathrm{dT})_{18}$ primers (TaKaRa, Japan).

\section{Full-length cDNA cloning}

To clone the cDNA, FABP sequences were downloaded from NCBI and aligned using ClustalX. A pair of degenerate primers, FABPF1 and FABPR1 (Table 1), was designed based on the conserved regions. The PCR was done in an ABI 2720 Thermal Cycler in a total volume of $25 \mu \mathrm{L}$ containing $2.5 \mu \mathrm{L}$ of $10 \mathrm{x}$ PCR buffer (containing $\left.\mathrm{Mg}^{2+}\right), 2.0 \mu \mathrm{L}$ of dNTP mix (2.5 mM each), $1 \mu \mathrm{L}$ of each primer $(10 \mu \mathrm{M}), 2 \mu \mathrm{L}$ of cDNA $(500 \mathrm{ng} / \mu \mathrm{L}), 0.125 \mu \mathrm{L}$ of Taq polymerase $(5 \mathrm{U} / \mu \mathrm{L}$; TaKaRa), and $16.375 \mu \mathrm{L}$ of RNase-free water. The PCR conditions were as follows: $94{ }^{\circ} \mathrm{C}$ for $5 \mathrm{~min}, 32$ cycles of $94{ }^{\circ} \mathrm{C}$ for $30 \mathrm{~s}, 46^{\circ} \mathrm{C}$ for $30 \mathrm{~s}$ and $72{ }^{\circ} \mathrm{C}$ for $30 \mathrm{~s}$, with a final extension at $72{ }^{\circ} \mathrm{C}$ for $10 \mathrm{~min}$. The PCR products were assessed visually after electrophoresison $1.2 \%$ agarose gels and those of appropriate size were purified, ligated into a pMD19-T Vector (TaKaRa) and then transformed in Escherichia coli by overnight culture. Positive clones with inserts of the predicted size were sequenced using the primers M13-47 and RV-M (Table 1) at Sangon Biotech Co., Ltd (Shanghai, China).

The 3' and 5' end fragments were completed by 3' and 5' rapid amplification of cDNA ends (RACE) with a 3', 5' full RACE kit (TaKaRa). Specific primers based on the initial sequence (FABP3RACE and FABP5RACE), together with a 3 ' outer primer and a 5 ' outer primer (Table 1), were used in the PCRs. The full length of $S p-F A B P$ was assembled by piecing together the 3 ' and 5 ' ends and the initial sequence. The sequence of the full-length cDNA was verified by using a pair of specific primers (FABPF2

Table 1 - Primers used in this study.

\begin{tabular}{lll}
\hline Primer name & Primer sequence (5'-3') & Application \\
\hline FABPF1 & TCBGARAACTTYGAYGAKTTC & cDNA cloning \\
FABPR1 & AVACRAYRTCATCDACYTTRC & cDNA cloning \\
M13-47 & CGCCAGGGTTTTCCCAGTCACG & Sequencing \\
RV-M & GAGCGGATAACAATTTCACACA & Sequencing \\
FABP3RACE & GCGAGGAGTTCGAGGAGACC & 3RACE \\
FABP5RACE & GGTCTCCTCGAACTCCTCGC & 5RACE \\
3Outerprimer & TACCGTCGTTCCACTAGTGATTT & 3RACE \\
5Outerprimer & CATGGCTACATGCTGACAGCCTA & 5RACE \\
FABPF2 & ACCAGTCGCGGGGAAGCCA & Full-length confirmation \\
FABPR2 & TTAGAATGTGGACATTTAATATATAAAGGTTA & Full-length confirmation \\
FABPF3 & CACACTTCACAGACCTTC & qRT-PCR \\
FABPR3 & CACAATGCCATCCTCTAC & qRT-PCR \\
Actin F & GAGCGAGAAATCGTTCGTGAC & Internal control \\
Actin R & GGAAGGAAGGCTGGAAGAGAG & Internal control \\
\hline
\end{tabular}


and FABPR2; Table 1) designed based on the preliminary sequencing results.

\section{Homology and phylogenetic analysis}

The Sp-FABP nucleotide and deduced amino acid sequences were compared to those reported for other organisms using the BLAST algorithm at the National Center for Biotechnology Information. The amino acid sequences of FABP from $S$. paramamosain and representative taxa were retrieved from NCBI GenBank and analyzed using ClustalX software. The open reading frame (ORF) of the cloned $S p-F A B P$ cDNA was determined with the ORF Finder, and SignalP 4.0 software was used to identify the putative signal peptide. Hydrophobic regions were predicted with Protscal. A neighbor-joining (NJ) phylogenetic tree was constructed using MEGA software v. 5.0 based on 1000 bootstraps.

\section{Real-time quantitative PCR analysis}

Total RNA levels of various mud crab tissues, of ovaries at different stages of development and of the hepatopancreas and hemocytes after bacterial challenge were examined by real-time quantitative PCR (qRT-PCR). The final volume of each qRT-PCR was $20 \mu \mathrm{L}$ and contained $10 \mu \mathrm{L}$ of 2 x SYBR Premix Ex Taq (TaKaRa), $1 \mu \mathrm{L}$ of diluted cDNA template, $0.5 \mu \mathrm{L}$ of each primer $(10 \mathrm{mM}$ FABPF3 and FABPR3; Table 1) and $8 \mu \mathrm{L}$ of PCR-grade water. A $\beta$-actin fragment was amplified using the primer pair Actin $\mathrm{F}$ and Actin R (Table 1) and served as an internal control (Huang et al., 2012). The cDNA template PCR conditions were as follows: $95^{\circ} \mathrm{C}$ for $30 \mathrm{~s}, 50$ cycles of $95^{\circ} \mathrm{C}$ for $10 \mathrm{~s}, 60^{\circ} \mathrm{C}$ for $30 \mathrm{~s}, 72{ }^{\circ} \mathrm{C}$ for $20 \mathrm{~s}$ and a final extension at $72^{\circ} \mathrm{C}$ for $10 \mathrm{~min}$. All samples were run in triplicate and the $S p-F A B P$ expression levels were calculated by the $2^{-\Delta \Delta C t}$ comparative $\mathrm{CT}$ method. The results were expressed as the mean $\pm \mathrm{SD}$ (standard deviation) of triplicate determinations and shown as the $\mathrm{n}$-fold difference relative to $\beta$-actin. Statistical comparisons were done using Students $t$-test and a value of $\mathrm{p}<0.05$ indicated significance.

\section{Results}

\section{Cloning and identification of $S p-F A B P$ cDNA}

A full-length ( $885 \mathrm{bp}$ ) FABP cDNA (Sp-FABP) was isolated from the ovaries of female mud crabs (GenBank: JQ824129). The sequence of the $S p-F A B P$ gene contained an ORF of $411 \mathrm{bp}$ (including the stop codon), with 5 ' and 3' untranslated regions of $67 \mathrm{bp}$ and $407 \mathrm{bp}$, respectively (Figure 1). A single polyadenylation signal (ATTAAA) was observed $856 \mathrm{bp}$ upstream of the 12 bp poly (A) tail. The ORF coded for a polypeptide of 136 amino acids, with a calculated molecular mass of $15,381.67 \mathrm{Da}$ and an isoelectric point of 5.55. Analysis of the $S p-F A B P$ cDNA sequence using ClustalX revealed significant similarity to

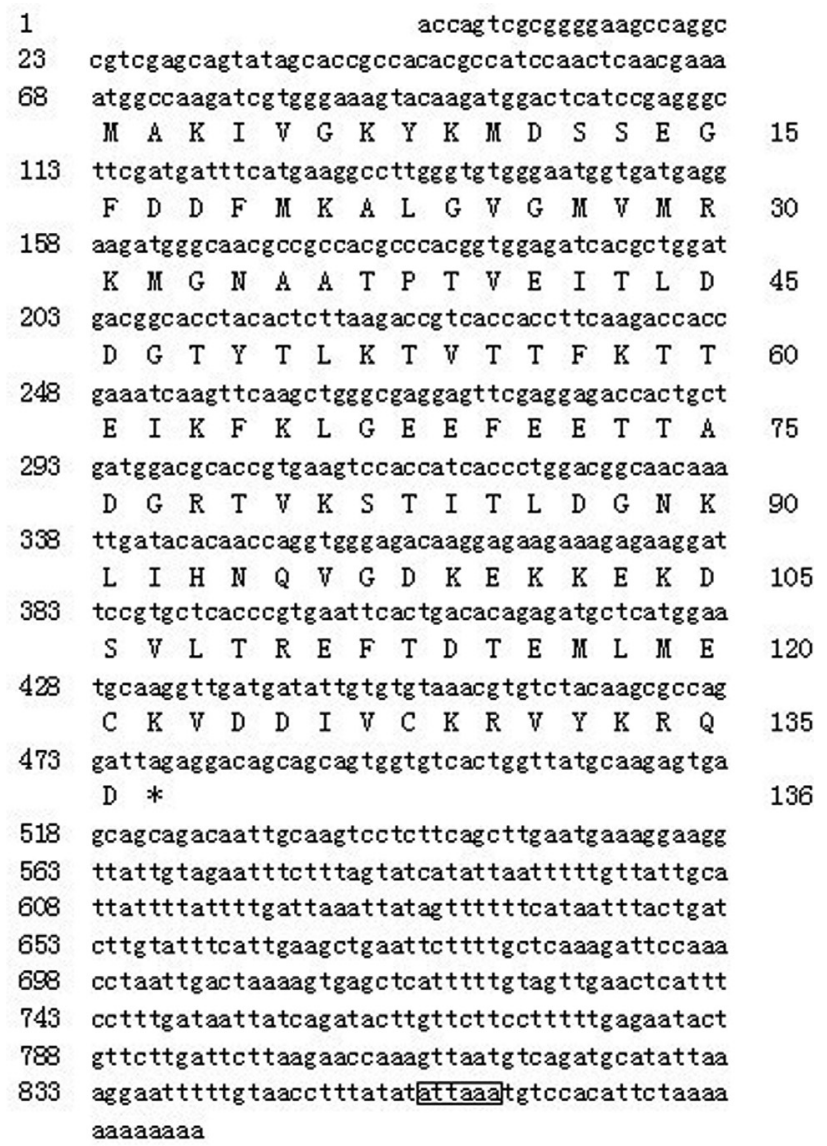

Figure 1 - Complete cDNA sequence (GenBank: JQ824129) and deduced amino acid sequence for $S p-F A B P$. The stop codon is marked by an asterisk. The polyadenylation signal (ATTAAA) is enclosed by a black rectangle.

the sequences of other FABPs included in the NCBI database. No signal peptide was identified by the SignalP 4.0 Server.

\section{Homology and phylogenetic analysis of $S p-F A B P$}

ClustalX alignment of the deduced amino acid sequence with other related sequences revealed a high degree of similarity: $85 \%$ identity with the shrimp Penaeus monodon, $83 \%$ identity with the Chinese mitten crab $E$. sinensis and $60 \%$ identity with the ant Acromyrmex echinatior (Figure 2).

An NJ phylogenetic tree was constructed based on reported FABP sequences using MEGA5.0 software (Figure 3). The reliability of the branching was tested by bootstrap resampling (with 1000 pseudo-replicates). Two distinct sister groups were observed, with a tree topology that agreed with traditional taxonomic relationships. The first group contained invertebrate FABPs (from E. sinensis, $S$. paramamosain, Penaeus monodon, Litopenaeus vannamei and Apis mellifera) while the second group contained vertebrate FABPs (Danio rerio, Salmo salar, Gallus gallus, Homo sapiens and Sus scrofa). 


H. sapiens
S. scrofa
G.gallus
S. salar
D. rerio
P. monodon
L. vannamei
E. sinensis
S. paramanosain
A. mellifera

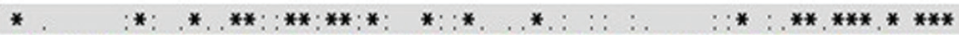
IVEAFCATWKLTNSONFDEYVKALGWGFATROVGNTKPTVIISOEGDKVIRTLSTFKNTEISFOLGE WVEFCATWKLTDSQNFDEYMKALGWGATROVGNTKPTVIISOEGDKVIRTQSTFKNTEISFHLGE IYEAFCATWKLADSHNFDEYMKAIGWGFAYROWGNVTKPTVIISSEGDKVIRTOSTFKNTEISFKLGE IVDAFCATWKLVDSDNFDEYMKALGGFATROVGNTKPTVIIAKEGDKVWKTOSTFKNTEISFKLGE WWDAFCGTWKLVSSDNFDEY WKSLGIGFATROVGNTKPTLVISKEGEKVWIKTOSTFKNTEISFTLGE YAKIEGK-FKMESSENFDEFMKALGVGUMRKMGNAATPTVEITKDGDTYAMKTTTTFKTTEIKFKLGE MAKIEGK-FKYESSENFDEFYKALGWGLUMRKMGNAATPTVEITKDGDTYTIKTTTTFKTTEIKFKLGE IAKIVGK-YKYES ENFDEF KAIGWGLVRKYGNAATPTVEITEEDGTYSYKTITTFKTTEIKFKLGE MAKIVGK-YKMDSSEGFDFVKALGWMVIRKMGNAATPTVEITLDDGTYTLKTVTTFKTTEIKFKLGE IPDFLGKRYKLYSSENEDDFMKALGWGIMTRKWGSSWSPWVELENNGLYTLKTTSPFKNTEIKFKLGE

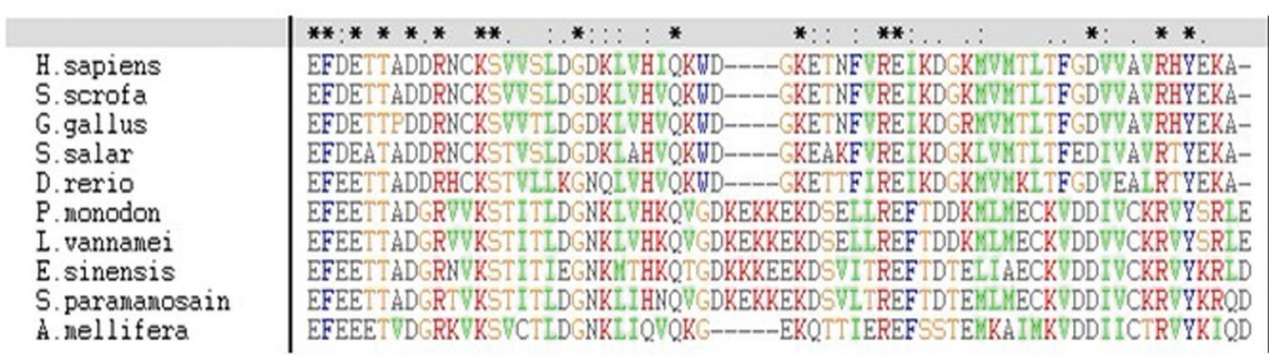

Figure 2 - ClustalX alignment of vertebrate and invertebrate FABP amino acid sequences. Alignment shows the following sequences (GenBank accession numbers in parentheses): Apis mellifera (NP 001011630.1), Danio rerio (NP 999972.1), Eriocheir sinensis (ADM64456.1), Gallus gallus (NP_990639.1), Homo sapiens (AAB87141.1), Litopenaeus vannamei (ADK66280.1), Penaeus monodon (ABE77154.1), Salmo salar (NP_001135371.1), Scylla paramamosain (JQ824129) and Sus scrofa (NP_001020400.1).

A homology model of Sp-FABP predicted using the SWISS-MODEL database revealed conservation of the tertiary structure, with the 10 anti-parallel $\beta$-strands forming a barrel and a clamshell-like structure.

\section{$S p-F A B P$ expression in different tissues and in ovaries at various reproductive stages}

qRT-PCR was used to investigate the distribution of $S p-F A B P$ mRNA in different tissues and to assess the expression of this gene in different female reproductive stages. $S p-F A B P$ showed variable levels of expression in a wide variety of tissues, including epidermis, eyestalk, gill, heart, hepatopancreas, hemocytes, muscle, ovary, stomach



Figure 3 - Neighbor-joining phylogenetic tree of representative vertebrate and invertebrate FABP amino acid sequences. Bootstrap values supporting the branch points are expressed as the percentage of 1000 replicates. The following organisms with FABPs were included in the analysis: Apis mellifera, Danio rerio, Eriocheir sinensis, Gallus gallus, Homo sapiens, Litopenaeus vannamei, Penaeus monodon, Salmo salar, Scylla paramamosain and Sus scrofa. See Figure 2 legend for GenBank accession numbers. and thoracic ganglia (Figure 4). Sp-FABP transcripts were constitutively expressed in mud crab ovary, although the level of expression varied with the stage of ovarian maturation. The expression of $S p-F A B P$ increased from reproductive stage I to stage IV, when it reached a peak, and then decreased significantly at stage V (Figure 5).

\section{$S p-F A B P$ expression in hepatopancreas and hemocytes after a bacterial challenge}

To gain insight into the involvement of FABP in the crab immune response, the expression profiles of $S p-F A B P$ were assessed by qRT-PCR after a bacterial challenge. The hepatopancreas showed an increase in the level of $S p-F A B P$ transcripts at all time intervals after the bacterial challenge, especially at $3 \mathrm{~h}$; after $3 \mathrm{~h}$, the expression of $S p-F A B P$ gradually decreased, but the levels were still higher than in the control group (Figure 6). In hemocytes,

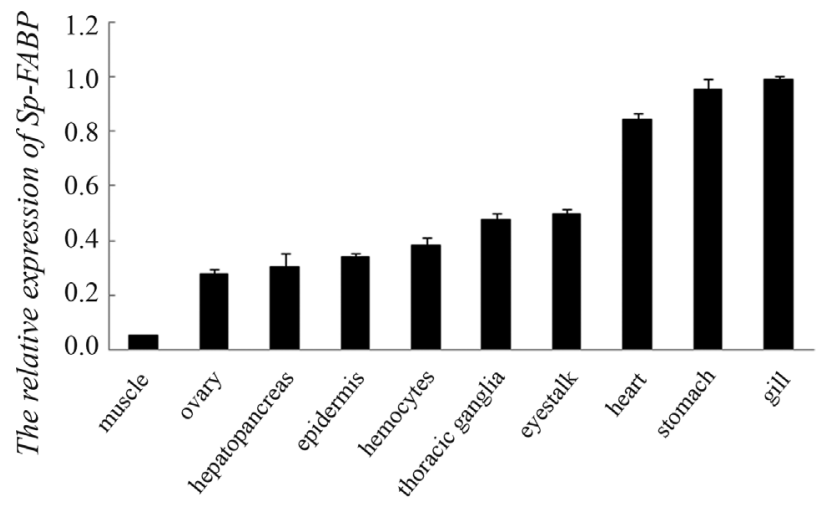

Figure 4 - Tissue distribution of $S p-F A B P$ expression as determined by qRT-PCR. The columns are the mean \pm SD $(n=3)$. 




Figure 5 - $S p-F A B P$ expression in different stages of ovarian development, as determined by qRT-PCR. The columns are the mean $\pm \mathrm{SD}(\mathrm{n}=3)$.

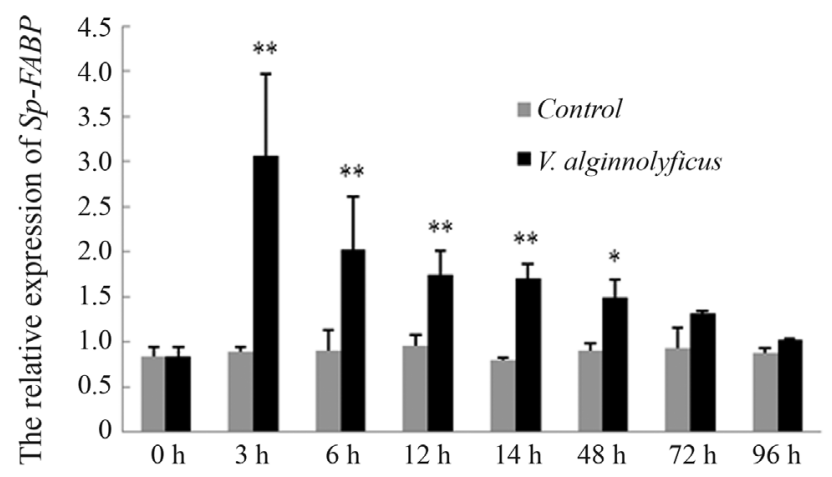

Figure 6 - Hepatopancreatic $S p-F A B P$ expression after a bacterial challenge with $V$. alginnolyficus, as determined by qRT-PCR. The relative abundance of the $S p-F A B P$ transcripts is expressed as the mean $\pm \mathrm{SD}$ $(\mathrm{n}=3) .{ }^{*} \mathrm{p}<0.05$ and $*_{\mathrm{p}}<0.01$ compared to the corresponding controls.

there was a slight increase in the level of $S p-F A B P$ transcripts at 3, 6 and $12 \mathrm{~h}$ post-challenge and a marked increase at 24, 48, 72 and $96 \mathrm{~h}$ post-challenge, with a peak at $72 \mathrm{~h}$ (Figure 7).

\section{Discussion}

FABPs belong to a large family of ubiquitous, lowmolecular-mass, small cytosolic lipid-binding proteins responsible for the non-covalent binding of hydrophobic ligands, primarily fatty acids (Zimmerman and Veerkamp, 2002). The biological roles of these proteins include a wide range of processes such as the transport, cellular uptake and cytoplasmic use of FAs, and FA-mediated regulation of gene expression (Esteves and Ehrlich, 2006). FABPs have been extensively studied in vertebrates whereas considerably less is known about these proteins in invertebrates.

In the current study, the full-length $S p-F A B P$ cDNA encoded a putative FABP of 136 amino acids with a theoretical molecular mass similar to that of other FABPs

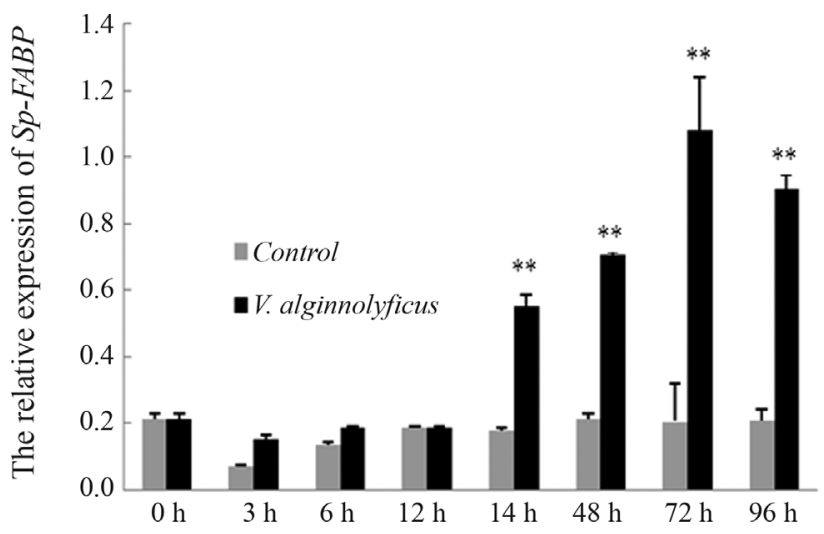

Figure 7 - $S p-F A B P$ expression in hemocytes after a bacterial challenge with $V$. alginnolyficus, as determined by qRT-PCR. The relative abundance of the $S p-F A B P$ transcripts is expressed as mean $\pm \mathrm{SD}(\mathrm{n}=3)$. ${ }^{*} \mathrm{p}<0.05$ and $* \mathrm{p}<0.01$ compared to the corresponding controls.

(127-136 amino acids) (Chen et al., 2006). The ClustalX alignment of Sp-FABP and nine other reported vertebrate and invertebrate FABP sequences revealed high identity (63-85\%) among invertebrate sequences. Three-dimensional homology modeling revealed that several key tertiary structures of Sp-FABP were similar to those of vertebrate FABPs, such as the ten anti-parallel $\beta$-strands, their resultant barrel with a clamshell-like structure, and the barrel cap consisting of a pair of $\alpha$-helices that enclose the cavity of the FABP lipid-binding site (Chmurzynska, 2006). These results confirmed the identity of the cloned $S p-F A B P$. Phylogenetic analysis revealed two distinct sister groups within the NJ tree: group 1 contained invertebrate FABPs whereas group 2 contained vertebrate FABPs. Evolutionarily, Sp-FABP is highly homologous to other FABPs and all FABPs are remarkably conserved.

Variable levels of $S p-F A B P$ transcripts were detected in epidermis, eyestalk, gill, heart, hemocytes, hepatopancreas, muscle, ovary, stomach and thoracic ganglia. The presence of $F A B P$ in all of the tissues examined suggested that $F A B P$ was ubiquitous and indispensable to crustacean growth. The expression levels were remarkably high in gill and stomach, which may be important for the following reasons. In crustaceans, the gill is a multifunctional organ, responsible for respiratory gas exchange, hemolymph acid-base and osmo-ionic regulation, and the excretion of nitrogenous metabolites (Freire et al., 2008), while the stomach is an important organ of the digestive system. Hence, $S p-F A B P$ may be involved in the maintenance and adjustment of essential physiological and pathological processes in the gill and stomach.

Ovarian expression of $S p-F A B P$ depended on the stage of ovarian maturation, with the level of expression increasing from stage I to stage IV (peak expression occurred in this stage) followed by a significant decrease in stage $\mathrm{V}$, in agreement with a previous study (Gong et al., 2010). During development, the ovary accumulates substantial 
amounts of nutritional substrates, especially FAs (Millamena, 1989; Shangguan and Liu, 1991; Mourente et al., 1994; Cheng et al., 2001). FAs accelerate the expression of FABP (Kaikaus et al., 1993a,b) because the tissue FABP content is associated with the rate of FA uptake and utilization (Ockner et al., 1980; Glatz and Vusse, 1990; van Breda et al., 1992). The variation in $S p-F A B P$ expression levels withdevelopmental stage suggests that FABP may be associated with ovarian maturation in the mud crab.

Although FABPs have been implicated in invertebrate immunity, there has not yet been any clear demonstration of a link between these two phenomena. In crustaceans, the hepatopancreas not only initiates the humoral immune response but also contains highly specialized cells and phagocytes that function in the cellular immune response (Pan et al., 2005). The invertebrate innate immune system provides the major defense mechanisms against pathogenic agents and the immune responses occur mainly in hemolymph (Somboonwiwat et al., 2006). The hepatopancreas and hemocytes are presumably the primary sites for the production of immune response factors. To investigate the relationship between FABP and the immune response, we initially injected bacteria into crabs and examined the expression of $S p-F A B P$ after the challenge. Sp-FABP expression was up-regulated in hepatopancreas and hemocytes after challenge with $V$. alginnolyficus, indicating that $S p-F A B P$ is inducible and is involved in the immune response. Transcripts of $S p-F A B P$ reached a peak at $3 \mathrm{~h}$ and then gradually decreased in hepatapancreas, while in hemocytes $S p-F A B P$ expression was significantly up-regulated at 24, 48, 72 and $96 \mathrm{~h}$ post-challenge, with a peak at $72 \mathrm{~h}$. Together, these findings indicate that $V$. alginnolyficus stimulated FABP expression as part of the host defense against infection, with the response being acute in hepatapancreas and gradual but persistent in hemocytes.

Crustacean diseases have received increasing attention because pathogens such as bacteria and viruses can adversely affect the commercial breeding of these species. FABP may also be involved in hemocyte production since hemocyte numbers are higher in crayfish Pacifastacus leniusculus and shrimp P. monodon (Söderhäll, 2006). The precise role and mechanism of FABP in the immune response to a bacterial challenge remains to be determined. Such information would improve our understanding of processes linked to cellular damage and repair in crabs, and help in the development of more effective methods for mitigating crab diseases.

In conclusion, the results of this study provide evidence for a role of $S p-F A B P$ in lipid metabolism during ovarian development and in the defense response after a bacterial challenge.

\section{Acknowledgments}

This research was supported by the National Natural Science Foundation of China (grants 40406030 and 41076081).

\section{References}

Becker MM, Kalinna BH, Waine GJ and McManus DP (1994) Gene cloning, overproduction and purification of a functionally active cytoplasmic fatty acid-binding protein $(\mathrm{Sj}-$ FABPc) from the human blood fluke Schistosoma japonicum. Gene 148:321-325.

Chen Z, Xu L and Shan A (2006) Fatty acid-binding proteins (FABPs) and their genes of FABPs. J Northeast Agric Univ 37:689-692.

Cheng W, Liu CH, Yeh ST and Chen JC (2004) The immune stimulatory effect of sodium alginate on the white shrimp Litopenaeus vannamei and its resistance against Vibrio alginolyticus. Fish Shellfish Immunol 17:41-51.

Cheng YX, Li SJ, Wang GZ, Chen XL, Lin QW and Xu J (2001) Changes in lipid class and fatty acid compositions in the ovaries and hepatopancreas of the mud crab Scylla serrata during the vitellogensis of the second ovarian maturation. Acta Oceanolog Sin 22:66-77.

Chmurzynska A (2006) The multigene family of fatty acid-binding proteins (FABPs): Function, structure and polymorphism. J Appl Genet 47:39-48.

Clarke SD (2000) Polyunsaturated fatty acid regulation of gene transcription: A mechanism to improve energy balance and insulin resistance. Br J Nutr 83:59-66.

Coburn CT, Knapp Jr FF, Febbraio M, Beets AL, Silverstein RL and Abumrad NA (2000) Defective uptake and utilization of long chain fatty acids in muscle and adipose tissues of CD36 knockout mice. J Biol Chem 275:32523-32529.

DeWille JW and Farmer SJ (1993) Linoleic acid controls neonatal tissue-specific stearoyl-CoA desaturase mRNA levels. Biochim Biophys Acta - Lipids Lipid Metab 1170:291-295.

Dhar AK, Dettori A, Roux MM, Klimpel KR and Read B (2003) Identification of differentially expressed genes in shrimp (Penaeus stylirostris) infected with White Spot Syndrome Virus by cDNA microarrays. Arch Virol 148:2381-2396.

Esteves A and Ehrlich R (2006) Invertebrate intracellular fatty acid binding proteins. Comp Biochem Physiol C Toxicol Pharmacol 142:262-274.

Estunningsih SE, Smooker PM, Wiedosari E, Widjajanti S, Vaiano S, Partoutomo S and Spithill TW (1997) Evaluation of antigens of Fasciola gigantica as vaccines against tropical fasciolosis in cattle. Int J Parasitol 27:1419-1428.

Freire CA, Onken H and McNamara JC (2008) A structurefunction analysis of ion transport in crustacean gills and excretory organs. Comp Biochem Physiol A Mol Integr Physiol 151:272-304.

Glatz JFC and Vusse GJ (1990) Cellular fatty acid-binding proteins: Current concepts and future directions. Mol Cell Biochem 98:237-251.

Gong YN, Li WW, Sun JL, Ren F, He L, Jiang H and Wang Q (2010) Molecular cloning and tissue expression of the fatty acid-binding protein (Es-FABP) gene in female Chinese mitten crab (Eriocheir sinensis). BMC Mol Biol 11:e71.

Graber R, Sumida C and Nunez EA (1994) Fatty acids and cell signal transduction. J Lipid Mediat Cell Signal 9:91-116.

Haunerl NH and Chisholm JM (1990) Fatty acid binding protein in flight muscle of the locust, Schistocerca gregaria. Biochim Biophys Acta - Lipids Lipid Metab 1047:233-238. 
Huang JR, Huang HY, Ye HY and Li SJ (2012) Cloning and analysis of $\beta$-actin gene from Scylla paramamosain. J Xiamen Univ (Nat Sci) 51:274-279.

Kaikaus RM, Chan WK, de Montellano PRO and Bass NM (1993a) Mechanisms of regulation of liver fatty acidbinding protein. Mol Cell Biochem 123:93-100.

Kaikaus RM, Sui Z, Lysenko N, Wu NY, Ortiz de Montellano PR, Ockner RK and Bass NM (1993b) Regulation of pathways of extramitochondrial fatty acid oxidation and liver fatty acid-binding protein by long-chain monocarboxylic fatty acids in hepatocytes. Effect of inhibition of carnitine palmitoyltransferase I. J Biol Chem 268:26866-26871.

Kang JX and Leaf A (1996) Evidence that free polyunsaturated fatty acids modify $\mathrm{Na}^{+}$channels by directly binding to the channel proteins. Proc Natl Acad Sci USA 93:3542-3546.

Le Vay L, Lebata MJH, Walton M, Primavera J, Quinitio E, Lavilla-Pitogo C, Parado-Estepa F, Rodriguez E, Ut VN and Nghia TT (2008) Approaches to stock enhancement in mangrove-associated crab fisheries. Rev Fish Sci 16:72-80.

Liu L, Barrett CF and Rittenhouse AR (2001) Arachidonic acid both inhibits and enhances whole cell calcium currents in rat sympathetic neurons. Am J Physiol-Cell Physiol 280:C1293-C1305.

Louet JF, Chatelain F, Decaux JF, Park EA, Kohl C, Pineau T, Girard J and Pegorier JP (2001) Long-chain fatty acids regulate liver carnitine palmitoyltransferase I gene (L-CPT I) expression through a peroxisome-proliferator-activated receptor $\alpha$ (PPAR $\alpha$ )-independent pathway. Biochem J 354:189-197.

Martin G, Schoonjans K, Lefebvre AM, Staels B and Auwerx J (1997) Coordinate regulation of the expression of the fatty acid transport protein and acyl-CoA synthetase genes by PPAR $\alpha$ and PPAR $\gamma$ activators. J Biol Chem 272:2821028217.

Millamena OM (1989) Effect of fatty acid composition of broodstock diet on tissue fatty acid patterns and egg fertilization and hatching in pond-reared Penaeus monodon. Asian Fish Sci 2:127-134.

Moser D, Tendler M, Griffiths G and Klinkert MQ (1991) A 14-kDa Schistosoma mansoni polypeptide is homologous to a gene family of fatty acid binding proteins. J Biol Chem 266:8447-8454.

Mourente G, Medina A, Gonzalez S and Rodriguez A (1994) Changes in lipid class and fatty acid contents in the ovary and midgut gland of the female fiddler crab Uca tangeri (Decapoda, Ocypodiadae) during maturation. Mar Biol 121:187-197.

Nunez EA (1997) Fatty acids involved in signal cross-talk between cell membrane and nucleus. Prostaglandins Leukot Essent Fatty Acids 57:429-434.

Ockner RK, Lysenko N, Manning JA, Monroe SE and Burnett DA (1980) Sex steroid modulation of fatty acid utilization and fatty acid binding protein concentration in rat liver. J Clin Invest 65:1013-1023.

Ordway RW, Singer JJ and Walsh JV (1991) Direct regulation of ion channels by fatty acids. Trends Neurosci 14:96-100.

Pan D, He N, Yang Z, Liu H and Xu X (2005) Differential gene expression profile in hepatopancreas of WSSV-resistant shrimp (Penaeus japonicus) by suppression subtractive hybridization. Dev Comp Immunol 29:103-112.

Ren Q, Du ZQ, Zhao XF and Wang JX (2009) An acyl-CoAbinding protein $(\mathrm{FcACBP})$ and a fatty acid binding protein
(FcFABP) respond to microbial infection in Chinese white shrimp, Fenneropenaeus chinensis. Fish Shellfish Immunol 27:739-747.

Rodríguez-Pérez J, García-Blanco MA and Hillyer GV (1992) Fasciola hepatica: Molecular cloning, nucleotide sequence, and expression of a gene encoding a polypeptide homologous to a Schistosoma mansoni fatty acid-binding protein. Exp Parasitol 74:400-407.

Shangguan B and Mand Liu ZC (1991) Histological studies on ovarian development in Scylla serrata. J Fish China 15:96103.

Söderhäll I, Tangprasittipap A, Liu HP, Sritunyalucksana K, Prasertsan P, Jiravanichpaisal P and Söderhäll K (2006) Characterization of a hemocyte intracellular fatty acid-binding protein from crayfish (Pacifastacus leniusculus) and shrimp (Penaeus monodon). FEBS J 273:2902-2912.

Somboonwiwat K, Supungul P, Rimphanitchayakit V, Aoki T, Hirono I and Tassanakajon A (2006) Differentially expressed genes in hemocytes of Vibrio harveyi-challenged shrimp Penaeus monodon. J Biochem Mol Biol 39:26-36.

Sumida C, Graber R and Nunez E (1993) Role of fatty acids in signal transduction: Modulators and messengers. Prostaglandins Leukot Essent Fatty Acids 48:117-122.

Tendler M, Brito CA, Vilar MM, Serra-Freire N, Diogo CM, Almeida MS, Delbem AC, Da Silva JF, Savino W and Garratt RC (1996) A Schistosoma mansoni fatty acid-binding protein, Sm14, is the potential basis of a dual-purpose anti-helminth vaccine. Proc Natl Acad Sci USA 93:269-273.

van Breda E, Keizer HA, Vork MM, Surtel DAM, de Jong YF, van der Vusse GJ and Glatz JFC (1992) Modulation of fatty-acid-binding protein content of rat heart and skeletal muscle by endurance training and testosterone treatment. Pflugers Archiv Eur J Physiol 421:274-279.

Wang B, Li F, Luan W, Xie Y, Zhang C, Luo Z, Gui L, Yan H and Xiang J (2008) Comparison of gene expression profiles of Fenneropenaeus chinensis challenged with WSSV and Vibrio. Mar Biotechnol 10:664-675.

Xiao YF, Gomez AM, Morgan JP, Lederer WJ and Leaf A (1997) Suppression of voltage-gated L-type $\mathrm{Ca}^{2+}$ currents by polyunsaturated fatty acids in adult and neonatal rat ventricular myocytes. Proc Natl Acad Sci USA 94:4182-4187.

Zeng Y and Lu CP (2009) Identification of differentially expressed genes in haemocytes of the crayfish (Procambarus clarkii) infected with white spot syndrome virus by suppression subtractive hybridization and cDNA microarrays. Fish Shellfish Immunol 26:646-650.

Zhao ZY, Yin ZX, Weng SP, Guan HJ, Li SD, Xing K, Chan SM and He JG (2007) Profiling of differentially expressed genes in hepatopancreas of white spot syndrome virus-resistant shrimp (Litopenaeus vannamei) by suppression subtractive hybridization. Fish Shellfish Immunol 22:520-534.

Zimmerman AW and Veerkamp JH (2002) New insights into the structure and function of fatty acid-binding proteins. Cell Mol Life Sci 59:1096-1116.

\section{Internet Resources}

ORF Finder, http://www.ncbi.nlm.nih.gov/gorf (June 5, 2012).

SignalP 4.0 software, http://www.cbs.dtu.dk/services/SignalP (June 5, 2012). 
Protscal, http://www.expasy.ch/tools/protscale.html (June 5, 2012). EGA software ver. 5.0, http://www.megasoftware.net (June 5, 2012).

SWISS-MODEL database, http://swissmodel.expasy.org (June 5, 2012).

License information: This is an open-access article distributed under the terms of the Creative Commons Attribution License, which permits unrestricted use, distribution, and reproduction in any medium, provided the original work is properly cited. 